\title{
Green Lynx Spider, Peucetia viridans (Hentz) (Arachnida: Araneae: Oxyopidae) ${ }^{1}$
}

H. V. Weems, Jr. and W. H. Whitcomb²

\section{Introduction}

In Florida, the green lynx spider, Peucetia viridans (Hentz), is the spider most often received for identification by Division of Plant Industry entomologists. It is a conspicuous, large, bright green spider found on many kinds of shrublike plants throughout the southern United States and is the largest North American lynx spider. Although it is common throughout Florida and aggressively attacks its insect prey, it very seldom bites humans. While its bite is of little concern to humans, the green lynx spider is of interest because of its potential use in agricultural pest management.

Judging from their local abundance, the lynx spiders are among the major predators of insects occurring in low shrubs and herbaceous vegetation. Few detailed observations have been made on the feeding habits of lynx spiders, but investigations by W.H. Whitcomb et al. (1963) have disclosed that the lynx spiders are important predators of crop-damaging insects. Oxyopes salticus Hentz, another lynx spider and one of the most common spiders in Arkansas cotton fields, has been reported by Whitcomb et al. (1963) as the chief predator of the bollworm, Heliothis zea (Boddie). Peucetia viridans is also an important predator of insect pests of cotton fields. In the field, green lynx spiders have been observed feeding on many species of moths of the families Noctuidae, Geometridae, and Pyralidae, including some of the most important crop pests. Whitcomb et al. (1963) reported these spiders feeding on bollworm moths, Heliothis zea (Boddie); cotton leafworm moths, Alabama agrillacea (Hübner); and cabbage looper moths, Trichoplusia ni (Hübner). They also capture larvae of these species.

However, their usefulness in the control of insect pests is counteracted by their willingness to prey also upon beneficial insects. These spiders seize large numbers of honey bees, Apis mellifera Linnaeus, and sphecid and vespid wasps. Whitcomb et al. (1963) reported that members of the vespid genus Polistes which, themselves, are important predators on crop pests, are especially favored as prey by lynx spiders. Similarly, several species of Diptera, including syrphid flies (pollinators) and large tachinid flies (beneficial parasites), also are seized. Thus the possible use of lynx spiders in the control of crop

1. This document is EENY-249 (originally published as DPI Entomology Circular 181), one of a series of Featured Creatures from the Entomology and Nematology Department, Florida Cooperative Extension Service, Institute of Food and Agricultural Sciences, University of Florida. Published: November, 2001. This document is also available on Featured Creatures Website at http://creatures.ifas.ufl.edu. Please visit the EDIS Website at http://edis.ifas.ufl.edu and the Entomology and Nematology Department website at http://entnemdept.ifas.ufl.edu/.

2. H. V. Weems, Jr., Florida Department of Agriculture and Consumer Services, Division of Plant Industry and W.H. Whitcomb, Department of Entomology and Nematology, University of Florida, Gainesville, FL.

The Institute of Food and Agricultural Sciences (IFAS) is an Equal Employment Opportunity - Affirmative Action Employer authorized to provide research, educational information and other services only to individuals and institutions that function without regard to race, creed, color, religion, age, disability, sex, sexual orientation, marital status, national origin, political opinions or affiliations. For information on obtaining other extension publications, contact your county Cooperative Extension Service office. Florida Cooperative Extension Service / Institute of Food and Agricultural Sciences / University of Florida / Larry R. Arrington, Interim Dean 
pests will depend in a large part on when, where, on what crops, and for the control of what pests they are to be used. Their use in Florida in the control of pests of such crops as soybeans and peanuts may be feasible. Their potential in this regard appears to warrant thorough investigation.

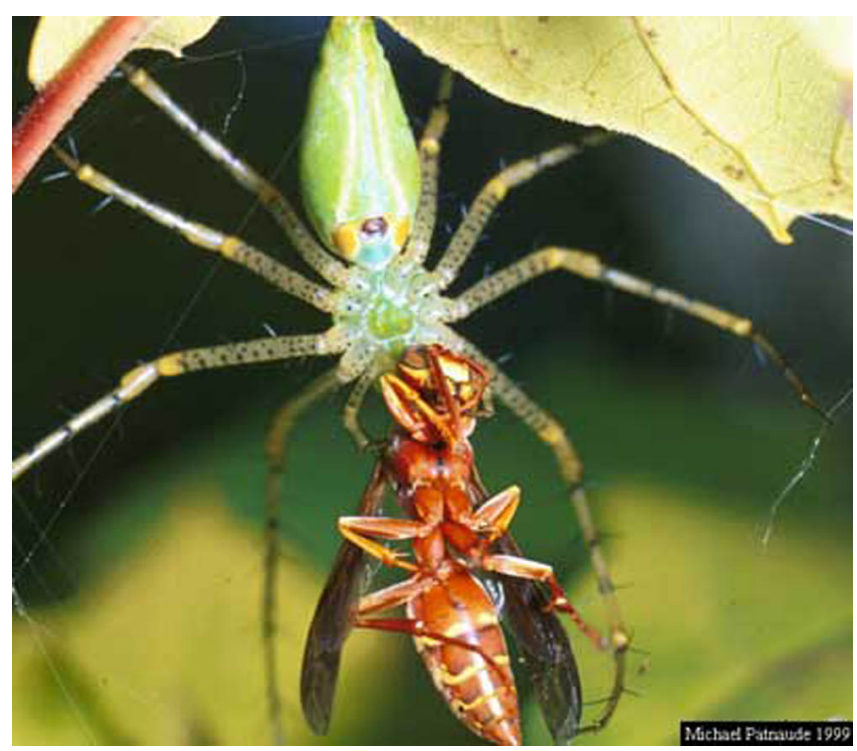

Figure 1. Ventral view of adult green lynx spider, Peucetia viridans (Hentz), attacking a wasp. Credits: Michael Patnaude, University of Florida

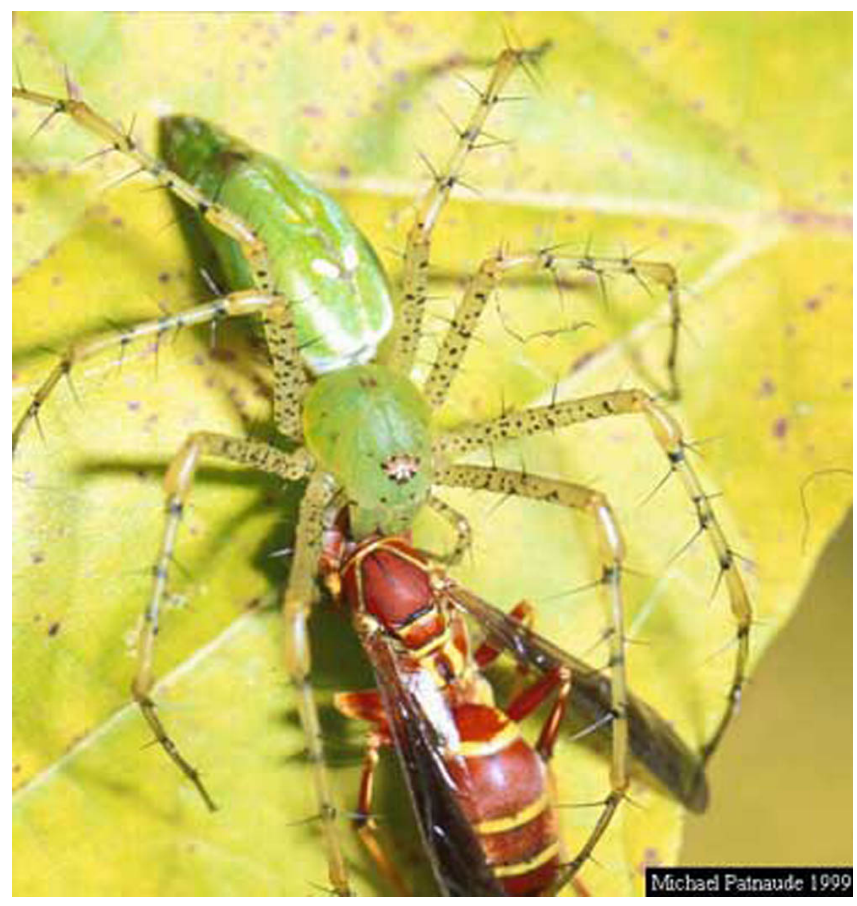

Figure 2. Dorsal view of adult green lynx spider, Peucetia viridans (Hentz), attacking a wasp. Credits: Michael Patnaude, University of Florida

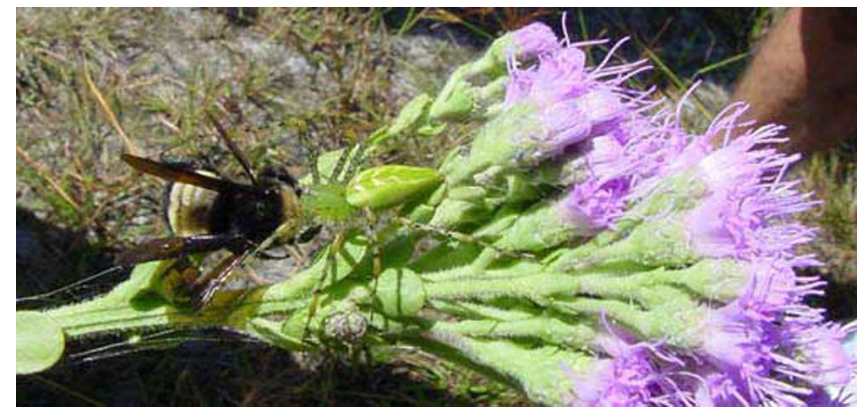

Figure 3. A green lynx spider, Peucetia viridans (Hentz), attacking a bumble bee on a paintbrush. Credits: Patrick Lamond, Osceola County Cooperative Extension Service, University of Florida

\section{Synonymy}

Sphasus viridans Hentz 1832: 105. Syntypes from North Carolina and Alabama, lost.

Clastes abboti Walckenaer 1838: 579. Holotype from Georgia, Abbot fig. 401.

Clastes viridis Walckenaer 1841: 475. Holotype from Georgia, Abbot fig. 406.

Clastes roseus Walckenaer 1841: 476. Holotype from Georgia, Abbot fig. 411.

Oxyopes viridans Hentz 1845: 195, pl. 17, fig. 2, female. 1875: 46, pl. 7, fig. 2, female.

Peucetia aurora McCook 1883: 277. 1890: 147, fig. 180-181. Female hologype from San Bernardino, California.

Peucetia viridans Emerton 1902: 89, fig. 220, female.

Peucetia abboti Chamberlin and Ivie 1944: 134.

This species was described under three names applied by Walckenaer $(1838,1841)$ to the Abbot drawings. The name Peucetia abboti was resurrected by Chamberlin and Ivie (1944), but Peucetia viridans (Hentz) has priority. Oxyopes fossanus Walckenaer, a still earlier name for $P$. viridans, was designed a nomen oblitum by Brady (1964).

\section{Distribution}

Two species of the genus Peucetia occur in North America. P. viridans (Hentz) occurs throughout most of the southern United States from 
coast to coast, Mexico, Central America, and the West Indies. P. longipalpis F.O. Pickard-Cambridge occurs in the southwestern United States, south to British Honduras.

\section{Identification}

The female $P$. viridans is a large spider often 12 to $22 \mathrm{~mm}$ in length, averaging approximately $16 \mathrm{~mm}$; the more slender, lighter male is somewhat smaller, averaging $12 \mathrm{~mm}$ in length. The cephalothorax is highest in the eye region, where it is quite narrow, but broadens out considerably behind. The body is bright transparent green in life (the vivid green pigment washes out rapidly in alcohol), and usually with a red patch between the eyes and with red spots over the body, as a whole varying in number and size. The eye region is clothed with white appressed hairs. Legs are paler green to yellow, quite long and thin, provided with very long, black spines, and covered with numerous black spots, particularly noticeable on the femora. Gertsch (1949) reported distinctive color variations in $P$. viridans, and Brady (1964) gave means for distinguishing $P$. viridans from $P$. longipalpis, particularly the males which have distinctively different genitalia.

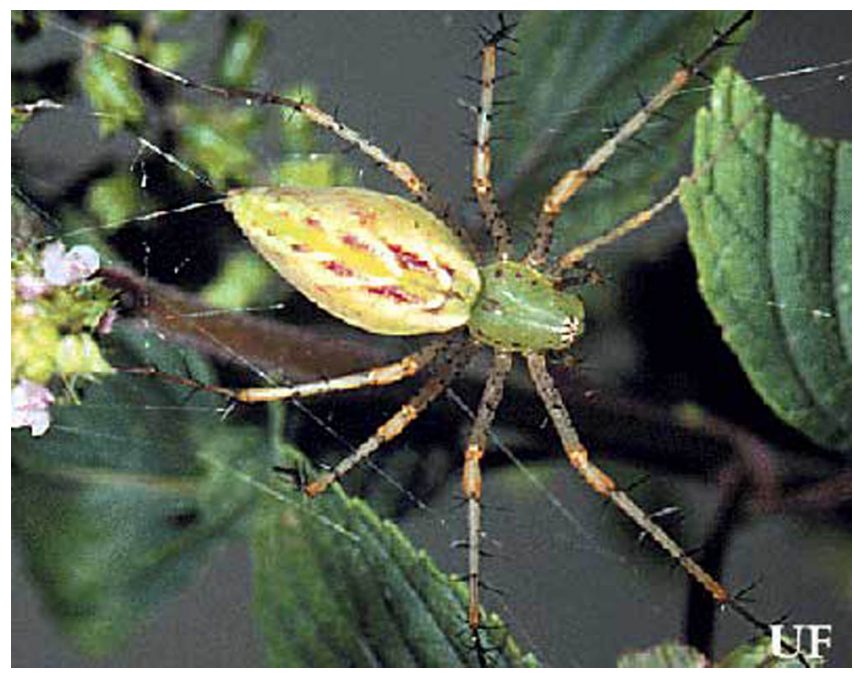

Figure 4. Adult green lynx spider, Peucetia viridans (Hentz). Credits: University of Florida

The oxyopids or lynx spiders, in general, can be distinguished readily from other families of spiders by their peculiar hexagonal eye arrangements and the prominent spines on the legs. Randall (1976, unpublished thesis) used the femoral spination as a key to instar determination.

\section{Life History, Habits, and Habitat}

P. viridans, in North America, has one generation a year under field conditions and apparently constructs one egg sac, typically in September and October, although two or more may be constructed in the southern part of its range. After an egg sac is constructed, the female guards it continuously and vigorously. Usually, she hangs upside down from the sac and will rush at anything that threatens it. Each egg sac contains 25 to 600 bright orange eggs, with an average of approximately 200 eggs. Eggs require 11 to 16 days to hatch, depending on air temperature. Each egg transforms to a postembryo (incorrectly called a deutovum in some of the literature). The postembryo of the green lynx, like that of other spiders, is without tarsal claws and mouth parts, and the eyes are functionless. No setae or hairs are present on the body.

The postembryo remains in the egg sac, where it molts after 10 to 16 days. The resulting first instar spiderling has functional eyes, a digestive tract, and spines, and is ready to leave the egg sac. Emergence from the egg sac occurs within 10 to 13 days after the eggs have hatched. The female spider helps the young to emerge by tearing open the egg sac soon after the first postembryos have molted. Unlike the wolf spiders, in an emergency green lynx spiderlings can make their own exit holes from the egg sac. Under field conditions, male and female spiderlings pass through eight instars before reaching sexual maturity, but less may be required under laboratory conditions. Brady (1964) recorded that, "under laboratory conditions the total time from egg sac emergence to maturity, in the case of reared males, averaged 288.6 days; in the case of reared females, 301 days." Males had six to seven instars; females had seven to eight instars.

Whitcomb et al. (1966) observed that the female constructs her egg sac 21 to 28 days after mating, which occurs in July and August. The egg sac is light green when first constructed but becomes straw colored with age. It is a rounded object 1.5 to $2.5 \mathrm{~cm}$ in diameter and flattened on one side; the thick outer coating has many small, pointed projections, with a maze of silken threads extending from the egg sac to nearby leaves and stems, investing the whole branch 
in a silken web where the young can remain until they are ready to fend for themselves. Most egg sacs are constructed in the upper branches of woody shrubs. Green lynx spiders overwinter as early instar spiderlings.

The green lynxes, like other Oxyopidae, are diurnal hunting spiders which run over low shrubs and herbs with great agility, leaping from place to place with a precision excelled only by the true jumping spiders. Their relatively keen eyesight is comparable to that of the wolf and fishing spiders. However, they may pause and assume a characteristic prey-catching posture to await their victims. Although they trail a dragline even when jumping, they do not make use of webs to capture their prey. The North American oxyopids are recognized readily in the field by the presence of numerous, large, erect spines on the legs and by their quick darting movements and sudden leaps.

\section{Selected References}

Banks N. 1904. The Arachnida of Florida. Proceedings of the National Academy of Science Philadelphia 56: 120-147.

Brady AR. 1964. The lynx spiders of North America, north of Mexico (Araneae: Oxyopidae). Bulletin of the Museum of Comparative Zoology 131: 429-518.

Chamberlin RV, Ivie W. 1944. Spiders of the Georgia region of North America. Bulletin of the University of Utah, biological series 8: 1-267.

Comstock JH. 1940. The Spider Book. revised ed., by Gertsch WJ. Doubleday and Co., New York. $729 \mathrm{p}$.

Emerton JH. 1902. The Common Spiders of the United States. Ginn and Co., Boston. 235 p.

Exline H, Frizzell DL, Whitcomb WH. 1965. Clarification of the mating procedure of Peucetia viridans (Araneida: Oxyopidae) by a microscopic examination of the epigynal plug. Florida Entomologist 48: 169-171.

Gertsch WJ. 1949. American Spiders. D. Van Nostrand Co., New York. 285 p.
Glick PA. 1939. The distribution of insects, spiders, and mites in the air. U.S. Department of Agriculture Technical Bulletin 673: 1-150.

Hentz NM. 1832. On North American spiders. American Journal of Science and Arts 21: 99-109.

Hentz NM. 1845. Descriptions and figures of the Araneides of the United States. Journal of the Boston Society of Natural History, Part III (1845) V: 189-202.

Hentz NM. 1875. The spiders of the United States. Boston Society of Natural History, Boston, Massachusetts. $171 \mathrm{p}$.

Kaston BJ. 1948. Spiders of Connecticut. State Geol. Natural History Survey, Connecticut 70: 1874.

Lowrie DC. 1963. Effects of grazing and intensive collecting on a population of the green lynx spider. Ecology 44: 777-781.

McCook HC. 1883. Note on two new Californian spiders and their nests. Proceedings of the National Academy of Science Philadelphia 35: 276-278.

McCook HC. 1890. American Spiders and Their Spinningwork. Vol. 2. (Pub. by the author.) Philadelphia, Pennsylvania. 479 p.

Petrunkevitch A. 1911. A synonymic index-catalogue of spiders of North, Central and South America with all adjacent islands. Bulletin of the American Museum of Natural History 29: 1-791.

Pickard-Cambridge FO. 1902. Biologia Centrali-Americana, Arachnida, Araneidea and Opilones. Vol. 2. Published for the editors by R.H. Porters. London. 610 p. + plates.

Randall JB. 1976. The use of femoral spination as a key to instar determination in the green lynx spider, Peucetia viridans Hentz. Unpublished thesis. University of Florida, Gainesville, FL. 26p.

Rea PM, Bragg LM. 1909. Local fauna. Spiders. Bulletin of the Charleston Museum 5: 65-66. 
Walckenaer CA. 1838. Histoire naturelle des insectes Apteres. Paris 1: 1-682.

Walckenaer CA. 1841. Histoire naturelle des insectes Apteres. Paris 2: 1-549.

Whitcomb WH. 1962. Egg sac construction and oviposition of the green lynx spider, Peucetia viridans (Oxyopidae). Southwestern Naturalist 7: 198-201.

Whitcomb WH, Eason R. 1965. The mating behavior of Peucetia viridans (Araneida: Oxyopidae). Florida Entomologist 48: 163-167.

Whitcomb WH, Exline H, Hunter RC. 1963. Spiders of the Arkansas cotton field. Annals of the Entomological Society of America 56: 653-660.

Whitcomb WH, Hite M, Eason R. 1966. Life history of the green lynx spider, Peucetia viridans (Araneida: Oxyopidae). Journal of the Kansas Entomological Society 39: 259-267. 